ОСОБЛИВОСТІ ПІЗНАВАЛЬНОЇ СФЕРИ СОМАТИЧНО ОСЛАБЛЕНИХ УЧНІВ ПОЧАТКОВИХ КЛАСІВ

\title{
COGNITIVE SPHERE CHARACTERISTICS OF SOMATICALLY WEAKENED PUPILS IN PRIMARY SCHOOL
}

у статті розкривається проблема визна-
чення особливостей пізнавальних процесів
соматично ослаблених учнів як категорії
дітей, які потребують особливого підходу у
процесі педагогічної взаємодії з ними. Викла-
даються теоретичні основи визначення
поняття соматично ослаблених дітей. у
зв'язку з необхідністю застосування індиві-
дуального підходу до таких учнів у навчаль-
ному процесі на основі розуміння специфріки
роботи їхньої когнітивної соери основна
увага приділяється представленню резуль-
татів дослідження показників пізнавальної
сфери соматично ослаблених учнів почат-
кових класів, зокрема показників уваги, розу-
мової працездатності, пам'яті, логічного
мислення, ступеня засвоєння навчальної
програми.

Виявлено, що загалом зі збільшенням частоти захворювань учнів стійкість уваги в них зменшується. Але значущих кореляційних зв'язків між стійкістю уваги учнів початкових класів та частотою і тривалістю їхньої захворюваності не встановлено.

Продуктивність роботи має обернений взаємозв'язок із кількістю захворювань на рік: чим частіше дитина хворіє, тим меншою $\epsilon$ ї продуктивність.

Достовірно менший обсяг короткочасної пам'яті молодших школярів, які часто хворіють, свідчить про зниження функціональних можливостей їхньої нервової системи.

Встановлені статистично значущі обернені кореляційні зв'язки між частотою захворювань учнів початкових класів і рівнем запам'ятовування, а також між тривалістю хвороб та рівнем запам'ятовування.

Рівень розвитку логічного мислення відносно здорових дітей, тих, які хворіють епізодично, і соматично ослаблених дітей достовірно не відрізняється.

Рівень навчальної успішності учнів початкових класів зменшується зі збільшенням частоти захворювань і тривалості хвороб.

Отже, у результаті експериментального дослідження виявлено таке: частота захворюваності та тривалість хвороб негативно впливають на такі когнітивні процеси, як: стійкість уваги, працездатність, рівень запам'ятовування та рівень логічного мислення, що в результаті проявляється в нижчій навчальній успішності соматично ослаблених діmей.

Ключові слова: соматично ослаблені учні, пізнавальна сфрера, стійкість уваги, про- дуктивність розумової діяльності, рівень запам'ятовування, логічне мислення, навчальні успішність.

The article is devoted to the problem of determining the features of cognitive processes of somatically weakened pupils as a category of children who need a special approach in the process of pedagogical interaction with them. Theoretical bases of somatically weakened children concept definition are stated. Due to the need to apply an individual approach to such pupils in the learning process based on the understanding of the specifics of their cognitive sphere, the main attention is paid to the presentation of indicators of somatically weakened primary school pupils cognitive sphere study results, including indicators of attention, mental capacity, memory, logical thinking, academic success.

It was found that in general, with increasing frequency of pupils' diseases, the stability of their attention decreases. However, there are no significant correlations between the stability of primary school pupils' attention and the frequency and duration of their illnesses.

The productivity is inversely related to the num ber of illnesses per year: the more often a child is ill, the lower his or her productivity.

The short-term memory of young pupils, who are often ill, is significantly less, that indicates a decrease in the functionality of their nervous system.

There are statistically significant inverse correlations between the diseases frequency and the level of memory of the primary school pupils, as well as between the duration of illnesses and the level of memory.

The level of logical thinking development of healthy children, those who are sick sporadically, and somatically weakened children does not differ significantly.

The level of primary school pupils' academic success decreases with the increase of frequence and duration of their illnesses.

Thus, the experimental study revealed the following facts: the frequence and duration of diseases negatively affect such cognitive processes as: stability of attention, productivity, memory level and logical thinking level of somatically weakened children, that results in their lower academic success.

Key words: somatically weakened pupils, cognitive sphere, stability of attention, productivity of mental activity, level of memorization, logical thinking, academic success.
Процеси, які відбуваються в сучасній освіті, безпосередньо стосуються проблеми ефективноїпедагогічноївзаємодіївчителятадитини. у зв'язку з оновленням освіти на принципах гуманізму та творчого підходу до розвитку кожної окремої особистості акцент на знання змінюється орієнтацією на всебічний розвиток особистості дитини. Основним завданням педагога нині є розвиток особистісного потен- ціалу дитини, забезпечення її емоційного комфорту, створення умов для іï успішної адаптації, соціалізації, особистісного розвитку. Окремою категорією дітей, які потребують особливогопідходу,єсоматичноослабленідіти.

На позначення дітей, які мають проблеми зі здоров'ям, науковці вживають різні терміни: «діти, які часто хворіють» [1]; «діти, які мають хронічні соматичні захворювання» [3; 5]; «діти, 
які мають важкі форми соматичних захворювань» [7]; «соматично хворі діти» [9]; «соматично ослаблені діти» [6].

Поняття «соматично ослаблені діти» у різних дослідженнях розуміється по-різному.

Так, Р.А. Каракетов до категорії соматично ослаблених дітей відносить як тих, які часто хворіють, так і тих, які мають хронічні або важкі соматичні захворювання [6].

С.С. Трусова називає соматично ослабленими тих дітей, які мають обмеження у стані їхнього здоров'я, унаслідок цього є виключенимизбезперервногонавчальногопроцесу[11].

Л.М. Шипицина, А.О. Хилько, Ю.С. Галямова, Р.В. Дем'янчук, Н.М. Яковлева відзначають, що група соматично ослаблених дітей $€$ різнорідною у зв'язку з тим, що різноманітними можуть бути причини, які викликають ослабленість дитини: несприятливі впливи під час внутрішньоутробного розвитку і під час пологів, часті психотравмувальні ситуації, гіповітамінози тощо [12].

У медичній та психологічній літературі соматичну ослабленість пов'язують передусім з астенічним синдромом, який виникає внаслідок частих захворювань.

Зокрема, А.І. Захаров визначає соматичну ослабленість організму як зниження захисних сил організму, вегетативну дисфункцію. Соматично ослаблені діти характеризуються частими захворюваннями на ГРВІ та різноманітні захворювання дихальних шляхів, повільним видужуванням, астенічним синдромом [4].

у нашому дослідженні до категорії соматично ослаблених учнів ми відносимо дітей, які часто хворіють на ГРВІ й інші захворювання, як-от отит, фарингіт, бронхіт, запалення легенів тощо.

Унаслідок частих або тривалих респіраторних захворювань такі учні є ослабленими, не готові справлятися з навантаженнями навчального процесу, емоційно нестійкі, вразливі.

I саме із цією категорією дітей у вчителів початкових класів можуть виникати проблеми, зумовлені нерозумінням психологічних та психофізіологічних особливостей.

У зв'язку 3 необхідністю застосування в педагогічній взаємодії індивідуального підходу до учнів на основі розуміння специфіки роботи їхньої когнітивної сфери нами було проведене дослідження показників пізнавальної сфери соматично ослаблених учнів початкових класів, зокрема показників уваги, розумової працездатності, пам'яті, логічного мислення, ступеня засвоєння навчальної програми.

Усі показники порівнювалися залежно від частоти захворюваності дітей та тривалості їх відсутності у школі внаслідок хвороб.

Така комплексна діагностика відповідала завданням цілісної оцінки особливостей когнітивної сфери соматично послаблених дітей, дозволила визначити можливі труднощі процесу навчання дітей цієї категорії.

У дослідженні взяли участь 220 учнів II-IV класів: 50 учнів II класу, 62 учні III класу і 108 учнів IV класу, з них 122 хлопця і 98 дівчаTOK.

Із 220 учнів II-IV класів, які взяли участь у дослідженні, 29,1\% хворіють 0-1 раз на рік, 47,3\% хворіють 2-3 рази на рік, 23,6\% 4 та більше разів на рік.

Під час розподілу досліджуваних за тривалістю хвороб на рік виявилося, що 26,4\% учнів хворіють 0-1 тиждень на навчальний рік, $37,3 \%$ - хворіють 2-3 тижні на рік, 24,5\% 4-5 тижнів на рік, $11,8 \%$ - 6 та більше тижнів на рік.

Наведемо отримані дані стосовно взаємозв'язків між частотою і тривалістю захворюваності й показниками пізнавальної сфери учнів початкової школи.

Для визначення стійкості уваги та рівня розумової працездатності нами була використана методика «Коректурна проба» [2].

Під час оброблення даних, отриманих за допомогою даної методики, визначалися стійкість уваги та продуктивність роботи учнів.

Показники стійкості уваги розподілялися на рівні (низький, середній, високий) за формулою:

$$
M \pm 1 / 2 \delta
$$

де М - середнє арифметичне,

$\delta$ - стандартне відхилення.

$$
\begin{aligned}
& M-1 / 2 \delta=0,77-0,06=0,71 ; \\
& M+1 / 2 \delta=0,77+0,06=0,78 .
\end{aligned}
$$

До низького рівня відносилися показники стійкості уваги від найменшого до 0,70 , до середнього - від 0,71 до 0,83, до високого від 0,84 до найвищого.

Результати дослідження стійкості уваги учнів початкових класів залежно від частоти та тривалості їхньої захворюваності представлені в таблиці 1.

Зі збільшенням частоти захворювань учнів стійкість уваги в них зменшується: високий рівень стійкості уваги мають 9,6\% учнів, які хворіють 4 та більше разів на рік, 22,1\% тих, хто хворіє 2-3 рази на рік, та $25,0 \%$ учнів, які хворіють 0-1 рази на рік.

Але значущих кореляційних зв'язків між стійкістю уваги учнів початкових класів та частотою і тривалістю їхньої захворюваності не встановлено $(\mathrm{Ro}=-0,1, \mathrm{p}>0,05 ; \mathrm{Ro}=-0,4$, $\mathrm{p}>0,05)$.

Продуктивність роботи розраховувалася за допомогою формули:

$$
\mathrm{E}=\mathrm{SA} \text {, }
$$

де $\mathrm{E}$ - продуктивність роботи;

S - кількість літер, які встиг продивитися досліджуваний; 
А - точність роботи.

Рівні продуктивності роботи визначалися за тією ж формулою, що і рівні стійкості уваги:

$$
\begin{aligned}
& M-1 / 2 \delta=444-64=380 \\
& M+1 / 2 \delta=444+64=508
\end{aligned}
$$

Отже, до низького рівня продуктивності відносилися показники до 379, до середнього від 380 до 508, до високого - від 509 і більше.

Результати дослідження продуктивності учнів початкових класів залежно від частоти та тривалості їх захворюваності представлені в таблиці 2.

Соматично ослаблені діти виконують менший обсяг роботи за визначений проміжок часу. Але якість виконаної роботи зберігається на досить високому рівні. Продуктивність роботи має обернений взаємозв'язок із кількістю захворювань на рік: чим частіше дитина хворіє, тим меншою є ї̈ продуктивність.

Загалом, у дівчат, незважаючи на частоту та тривалість хвороб, як стійкість уваги, так і продуктивність $€$ вищими, ніж у хлопців.

Встановлені статистично значущі обернені кореляційні зв'язки між частотою захворювань учнів початкових класів і продуктивністю їхньої роботи $(R o=-0,2, p<0,01)$, а також міжтривалістюхворобтапродуктивністюроботи $(\mathrm{Ro}=-0,2$, $\mathrm{p}<0,05)$, що свідчить про те, що зі збільшенням частоти захворювань і тривалості хвороб продуктивність роботи учнів зменшується.

Якісний аналіз результатів «коректурної проби» дозволив виділити таку особливість уваги дітей, які часто хворіють, як здатність до їі мобілізації. У відносно здорових дітей та дітей, які хворіють епізодично, якість виконання роботи знижується одномірно і поступово. У соматично ослаблених дітей можливе поліпшення результатів роботи після «спаду» якості, але обсяг роботи, виконаний за певний час соматично ослабленими учнями, є значно меншим, ніж у тих учнів, які хворіють менше.

Наступним кроком було визначення особливостей розвитку пам'яті, які досліджувалися нами за допомогою методики заучування десяти слів О.Р. Лурії [8].

Особливості запам'ятовування учнів початкових класів із різною частотою та тривалістю захворювань представлені в таблиці 3.

Про зниження функціональних можливостей нервової системи свідчить достовірно менший обсяг короткочасної пам'яті молодших школярів, які часто хворіють.

Встановлені статистично значущі обернені кореляційні зв'язки між частотою захворювань учнів початкових класів і рівнем запам'ятовування $(R o=-0,4, p<0,01)$, а також між тривалістю хвороб та рівнем запам'ятовування $(R o=-0,3, p<0,01)$, що свідчить про те, що зі збільшенням частоти захворювань і тривалості хвороб рівень запам'ятовування учнів зменшується.

Так, високий рівеньзапам'ятовування мають 3,8\% учнів, які хворіють 4 та більше разів на рік. Серед учнів, які хворіють 2-3 рази на рік, висо-

Розподіл учнів початкових класів за рівнем стійкості уваги залежно від частоти та тривалості їхньої захворюваності, \%

\begin{tabular}{|c|l|c|c|c|}
\hline \multirow{2}{*}{ Критерій } & \multicolumn{1}{|c|}{ Показник } & \multicolumn{3}{c|}{ Рівень стійкості уваги } \\
\cline { 2 - 4 } & \multicolumn{1}{|c|}{ низький } & середній & високий \\
\hline \multirow{3}{*}{$\begin{array}{c}\text { Частота захворюваності } \\
\text { (на рік) }\end{array}$} & $0-1$ раз & 34,4 & 40,6 & 25,0 \\
\cline { 2 - 5 } & $2-3$ рази & 29,8 & 48,1 & 22,1 \\
\cline { 2 - 5 } & 4 та більше & 42,3 & 48,1 & 9,6 \\
\hline \multirow{3}{*}{\begin{tabular}{c} 
Tривалість захворювань $\begin{array}{c}\text { (на рік) } \\
\text { (1) }\end{array}$ \\
\cline { 2 - 5 }
\end{tabular}} & 2-3 тиждень & 34,5 & 44,8 & 20,7 \\
\cline { 2 - 5 } & $4-5$ тижнів & 29,3 & 46,3 & 24,4 \\
\cline { 2 - 5 } & 6 та більше тижнів & 48,1 & 38,9 & 13,0 \\
\hline
\end{tabular}

Розподіл учнів початкових класів за рівнем продуктивності розумової діяльності залежно від частоти та тривалості їх захворюваності, \%

\begin{tabular}{|c|l|c|c|c|}
\hline \multirow{2}{*}{ Критерій } & \multicolumn{1}{|c|}{ Показник } & \multicolumn{3}{c|}{ Рівень продуктивності } \\
\cline { 2 - 5 } & \multicolumn{1}{|c|}{ низький } & середній & високий \\
\hline \multirow{2}{*}{$\begin{array}{c}\text { Частота захворюваності } \\
\text { (на рік) }\end{array}$} & $0-1$ раз & 25,0 & 37,5 & 37,5 \\
\cline { 2 - 5 } & 2-3 рази & 36,5 & 36,5 & 26,9 \\
\cline { 2 - 5 } & 4 та більше & 46,2 & 38,5 & 15,4 \\
\hline \multirow{3}{*}{$\begin{array}{c}\text { Тривалість захворювань } \\
\text { (на рік) }\end{array}$} & $0-1$ тиждень & 24,1 & 37,9 & 37,9 \\
\cline { 2 - 5 } & 2-3 тижні & 34,1 & 39,0 & 26,8 \\
\cline { 2 - 5 } & $4-5$ тижнів & 51,9 & 33,3 & 14,8 \\
\cline { 2 - 5 } & 6 та більше тижнів & 30,8 & 38,5 & 30,8 \\
\hline
\end{tabular}


Розподіл учнів початкових класів за рівнем запам'ятовування залежно від частоти та тривалості їхньої захворюваності, \%

\begin{tabular}{|c|c|c|c|c|}
\hline \multirow{2}{*}{ Критерій } & \multirow{2}{*}{ Показник } & \multicolumn{3}{|c|}{ Рівень запам'ятовування } \\
\hline & & низький & середній & високий \\
\hline \multirow{3}{*}{$\begin{array}{c}\text { Частота захворюваності } \\
\text { (на рік) }\end{array}$} & $0-1$ раз & 12,5 & 31,3 & 56,3 \\
\hline & 2-3 рази & 30,8 & 32,7 & 36,5 \\
\hline & 4 та більше & 46,2 & 50,0 & 3,8 \\
\hline \multirow{4}{*}{$\begin{array}{c}\text { Тривалість захворювань } \\
\text { (на рік) }\end{array}$} & 0-1 тиждень & 17,2 & 34,5 & 48,3 \\
\hline & 2-3 тижні & 26,8 & 24,2 & 48,8 \\
\hline & 4-5 тижнів & 37,0 & 48,1 & 14,8 \\
\hline & 6 та більше тижнів & 46,2 & 53,8 & - \\
\hline
\end{tabular}

Розподіл учнів початкових класів за рівнем довготривалої пам'яті

Таблиця 4 залежно від частоти та тривалості їхньої захворюваності, \%

\begin{tabular}{|c|c|c|c|c|}
\hline \multirow{2}{*}{ Критерій } & \multirow{2}{*}{ Показник } & \multicolumn{3}{|c|}{ Рівень довготривалої пам'яті } \\
\hline & & низький & середній & високий \\
\hline \multirow{3}{*}{$\begin{array}{c}\text { Частота захворюваності } \\
\text { (на рік) }\end{array}$} & $0-1$ раз & 21,9 & 21,9 & 56,3 \\
\hline & 2-3 рази & 21,2 & 40,4 & 38,5 \\
\hline & 4 та більше & 26,9 & 53,8 & 19,2 \\
\hline \multirow{4}{*}{$\begin{array}{c}\text { Тривалість захворювань } \\
\text { (на рік) }\end{array}$} & 0-1 тиждень & 24,1 & 27,6 & 48,3 \\
\hline & 2-3 тижні & 24,4 & 31,7 & 43,9 \\
\hline & 4-5 тижнів & 18,5 & 55,6 & 25,9 \\
\hline & 6 та більше тижнів & 23,1 & 46,2 & 30,8 \\
\hline
\end{tabular}

Таблиця 5

Розподіл учнів початкових класів за рівнем розвитку логічного мислення залежно від частоти та тривалості їхньої захворюваності, \%

\begin{tabular}{|c|c|c|c|c|c|c|}
\hline \multirow[b]{2}{*}{ Критерій } & \multirow[b]{2}{*}{ Показник } & \multicolumn{5}{|c|}{ Рівень розвитку логічного мислення } \\
\hline & & низький & $\begin{array}{c}\text { нижче } \\
\text { середнього }\end{array}$ & середній & $\begin{array}{c}\text { вище } \\
\text { середнього }\end{array}$ & високий \\
\hline \multirow{3}{*}{$\begin{array}{c}\text { Частота } \\
\text { захворюваності } \\
\text { (на рік) }\end{array}$} & 0-1 раз & 9,7 & 16,1 & 41,9 & 16,1 & 16,1 \\
\hline & 2-3 рази & 15,4 & 23,1 & 40,4 & 15,4 & 5,8 \\
\hline & 4 та більше & 19,2 & 7,7 & 26,9 & 34,6 & 11,5 \\
\hline \multirow{4}{*}{$\begin{array}{c}\text { Тривалість } \\
\text { захворювань } \\
\text { (на рік) }\end{array}$} & 0-1 тиждень & 10,7 & 14,3 & 39,3 & 21,4 & 14,3 \\
\hline & 2-3 тижні & 17,1 & 26,8 & 36,6 & 12,2 & 7,3 \\
\hline & 4-5 тижнів & 14,8 & 11,1 & 40,7 & 25,9 & 7,4 \\
\hline & 6 та більше тижнів & 15,4 & 7,7 & 30,8 & 30,8 & 15,4 \\
\hline
\end{tabular}

Розподіл учнів початкових класів за рівнем навчальної успішності залежності

Таблиця 6 від частоти та тривалості їхньої захворюваності, \%

\begin{tabular}{|c|c|c|c|c|c|c|}
\hline \multirow{2}{*}{ Критерій } & \multirow{2}{*}{ Показник } & \multicolumn{5}{|c|}{ Рівень навчальної успішності } \\
\hline & & незадовільний & низький & задовільний & достатній & високий \\
\hline \multirow{3}{*}{$\begin{array}{c}\text { Частота } \\
\begin{array}{c}\text { захворюваності } \\
\text { (на рік) }\end{array}\end{array}$} & 0-1 раз & - & - & 9,4 & 43,8 & 46,9 \\
\hline & 2-3 рази & - & - & 15,4 & 50,0 & 34,6 \\
\hline & 4 та більше & - & - & 38,5 & 50,0 & 11,5 \\
\hline \multirow{4}{*}{$\begin{array}{c}\text { Тривалість } \\
\text { захворювань } \\
\text { (на рік) }\end{array}$} & 0-1 тиждень & - & - & 10,3 & 44,8 & 44,8 \\
\hline & 2-3 тижні & - & - & 17,1 & 46,3 & 36,6 \\
\hline & 4-5 тижнів & - & - & 29,6 & 51,9 & 18,5 \\
\hline & 6 та більше тижнів & - & - & 23,1 & 53,8 & 23,1 \\
\hline
\end{tabular}


кий рівень запам'ятовування мають 19,4\%, а серед тих, хто хворіє 0-1 раз на рік, $-48,0 \%$.

Жоден з учнів, які хворіють 6 та більше тижнів на рік, не має високого рівня запам'ятовування. Високий рівень запам'ятовування мають 14,8\% учнів, які хворіють 4-5 тижнів на рік, 48,8\% тих, які хворіють 2-3 тижні, і 48,3\% тих, які хворіють 0-1 тиждень на рік.

Водночас рівень запам'ятовування в дівчаток у всіх групах вищий, ніж у хлопчиків.

Розподіл учнів початкових класів за рівнем довготривалої пам'яті залежно від частоти та тривалості їхньої захворюваності представлений у таблиці 4.

Встановлені статистично значущі обернені кореляційні зв'язки між частотою захворювань учнів початкових класів і об'ємом довготривалої пам'яті (Ro $=-0,2, p<0,01)$, що свідчить про те, що зі збільшенням частоти захворювань об'єм довготривалої пам'яті учнів зменшується.

Так, високий рівень об'єму довготривалої пам'яті мають 19,2\% учнів початкових класів, які хворіють 4-5 тижнів на рік, 38,5\% тих, які хворіють 2-3 тижні, і 56,3\% тих, які хворіють 0-1 тиждень на рік.

Для діагностики сформованості логічних операцій молодших школярів була використана методика «Словесні субтести», розроблена Е.Ф. Замбацявічене [10].

У таблиці 5 представлений розподіл учнів початкових класів за рівнем розвитку логічного мислення залежно від частоти та тривалості їхньої захворюваності. Як видно з таблиці, частота та тривалість захворювань учнів початкових класів не впливає на розвиток їхнього логічного мислення. Так, високий рівень логічного мислення мають 16,1\% відносно здорових дітей, 5,8\% тих, які хворіють епізодично, і $11,5 \%$ тих, які хворіють часто.

У результаті аналізу залежності рівня розвитку логічного мислення від тривалості захворювань виявилося, що вищий рівень розвитку логічного мислення мають ті діти, які хворіють 0-1 тиждень та 6 і більше тижнів на рік (14,3\% та 15,4\%). Серед учнів, які хворіють 2-3 та 4-5 тижнів, високий рівень розвитку логічного мислення спостерігається вдвічі рідше: 7,3\% та 7,4\%.

Отже, рівень розвитку логічного мислення відносно здорових дітей, тих, які хворіють епізодично, і соматично ослаблених дітей достовірно не відрізняється.

Аналіз навчальної успішності полягав у розрахунку загального показника успішності навчання дітей (середній бал за річними оцінками з основних предметів). Високому рівню навчальної успішності відповідав середній бал у діапазоні від 10 до 12, достатньому - від 7 до 9, задовільному - від 4 до 6, незадовільному - від 1 до 3.
Навчальна успішність учнів за рівнем навчальної успішності залежно від частоти та тривалості їхньої захворюваності представлена в таблиці 6.

Встановлені статистично значущі обернені кореляційні зв'язки між частотою захворювань учнів початкових класів і рівнем навчальної успішності (Ro $=-0,3, p<0,01)$, а також між тривалістю захворювань і рівнем навчальної успішності (Ro $=-0,2, p<0,01$ ), що свідчить про те, що зі збільшенням частоти захворювань і тривалості хвороб рівень навчальної успішності учнів початкових класів зменшується.

у процесі оцінки навчальної успішності учнів початкових класів виявилося, що високий рівень навчальної успішності мають 46,9\% відносно здорових учнів, 34,6\% тих, які хворіють епізодично. і лише 11,5\% соматично ослаблених.

Відповідно високу навчальну успішність мають 44,8\% учнів, які хворіють 0-1 тиждень на рік, 36,6\% учнів, які хворіють 2-3 тижні на рік, 18,5\% учнів, які хворіють 4-5 тижнів на рік, і 23,1\% учнів, які хворіють 6 та більше тижнів на рік. Тобто зі збільшенням кількості захворювань кількість дітей, які мають високий рівень навчальної успішності, знижується.

За результатами проведеного експериментального дослідження пізнавальних процесів учнів початкових класів можна зробити висновок, що такі чинники, як частота захворюваності та тривалість хвороб, негативно впливають на такі когнітивні процеси, як: стійкість уваги, працездатність, рівень запам'ятовування та рівень логічного мислення, що в результаті проявляється в нижчій навчальній успішності соматично ослаблених дітей.

Ці факти важливо використовувати для побудови ефективної педагогічної взаємодії з дітьми цієї категорії. Зокрема, важливе використання педагогами методів активізації уваги та руханок, адже внаслідок астенічного синдрому, притаманного соматично ослабленим учням, страждають всі пізнавальні процеси. Також у роботі із соматично ослабленими учнями необхідне створення позитивноемоційної атмосфери у класі для запобігання погіршенню показників пізнавальної діяльності під впливом стресу.

У зв'язку з вищепереліченим доречним є не тільки включення отриманих експериментальних даних до змісту курсів підвищення кваліфікації вчителів початкових класів, а й відпрацювання педагогами практичних навичок ефективної педагогічної взаємодії з учнями цієї категорії.

Для комплексного формування інформаційного, операційного, мотиваційного й особистісного компонентів психологічної готовності педагогів до роботи з такими дітьми 
нами розроблений тренінг психологічної підготовки вчителів початкових класів до взаємодії із соматично ослабленими учнями.

\section{ЛІТЕРАТУРА:}

1. Бадьина Н.П. Часто болеющие дети. Психологическое сопровождение в начальной школе. Москва, 2007. 152 с.

2. Баскакова И.Л. Внимание дошкольника, методы его изучения и развития. Изучение внимания школьников. Москва ; Воронеж, 1995. 64 с.

3. Григорьева Е.А., Хохлов Л.К. К проблеме психосоматических, соматопсихических отношений. Обозрение психиатрии и медицинской психологии им. В.М. Бехтерева. 2011. № 2. С. 30-33.

4. Захаров А.И. Детские неврозы: Психологическая помощь родителям, детям. Санкт-Петербург, 1995. 192 c.

5. Исаев Д.Н. Эмоциональный стресс, психосоматические и соматопсихические расстройства у детей. Санкт-Петербург, 2005. 400 с.
6. Каракетов Р.А. О специсрике индивидуального стиля деятельности соматически ослабленных студентов. Среднее профрессиональное образование. 2014. № 1. C. 45-47.

7. Лешин В.В. Учебная деятельность учащихся с тяжелыми формами соматических заболеваний. Вопросы психологии. 2008. № 6. С. 65-75.

8. Лурия А.Р. Альманах психологических тестов. Москва, 1995. 150 с.

9. Николаева В.В., Соколова Е.Т. Личность в условиях хронического соматического заболевания. Особенности личности при пограничных расстройствах и соматических заболеваниях. Москва, 1995. 360 c.

10. Психология детства / под ред. А.А. Реана. Санкт-Петербург, 2008. 350 с.

11. Трусова С.С. Организация воспитательной работы с соматически ослабленными детьми в лечебно-образовательном учреждении : автореср. дис. ... канд. пед. наук: 13.00.02. Кострома, 2006. 22 с.

12. Комплексное сопровождение детей дошкольного возраста / Л.М. Шипицына и др. ; под научн. ред. Л.М. Шипицыной. Санкт-Петербург, 2003. 240 с. 